\title{
Agronomic evaluation of a collection of French perennial ryegrass populations: multivariate classification using genotype $x$ environment interactions
}

\author{
G Charmet 1, F Balfourier 2, A Bion 1 \\ 1 INRA, Station d'Amélioration des Plantes, 63039 Clermont-Ferrand; \\ 2 INRA, Domaine Expérimental Fourrager, 61310 Le Pin-au-Haras, France
}

(Received 14 December 1990; accepted 17 October 1990)

\begin{abstract}
Summary - Five hundred and forty-seven natural populations of perennial ryegrass were collected as seeds from all over France in 1983 and 1984, then evaluated at 9 sites in spaced plant nurseries. Ten traits of agronomic interest were observed over a 3-yr life cycle. An analysis of variance of these traits for 3 sites with a complete data set revealed the considerable importance of population $x$ location interactions in the total variation for 6 out of the 10 traits: the susceptibilities and vigor traits. Principal component analyses were carried out on the interaction terms in 8 locations for each trait, which allowed the reduction to 4 as the minimum number of locations required to describe the most important part of interactions. A hierarchical clustering method was thus carried out using adjusted means of the 4 stable traits (absence of vernalisation requirement for flowering, growth habit, aftermath heading and heading date) or phenotypic means of the 6 others (rust susceptibility, frost susceptibility, spring, summer and autumn growth and persistence) in each of the 4 locations retained. A partition into 11 clusters was chosen from the view of the tree, accounting for more than $50 \%$ of the inertia. Each cluster was described by the mean of each trait and by its location on the map. One cluster (10) show a good performance in every location compared with control cultivars for every trait which show significant deviation from the general mean, except persistence in one location. Other clusters show more specific adaptation, ie they are above average in only one evaluation site. Good behavior at Mont de Marsan (South France) of the local populations of the surrounding region was observed.
\end{abstract}

The evolutionary implications and usefulness of this type of typology for genetic resource management and plant breeding are discussed.

Lolium perenne L / genetic resources / multivariate clustering / natural population / genotype x environment interaction

Résumé - Évaluation agronomique d'une collection de populations françaises pérennes de ray-grass : classification multivariable utilisant les interactions génotype $x$ environnement. Cinq cent quarante sept populations naturelles de ray-grass anglais ont été collectées sous forme de semences en 1983 et 1984, puis évaluées sur l'ensemble du territoire français métropolitain (fig 2) dans le cadre du programme coopératif ACVF-INRA avec le soutien du ministère de la 'Agriculture. Ces populations ont été évaluées en 9 lieux (fig 1) en pépinières de plantes espacées sur lesquelles 10 caractères d'intérêt agronomique ont été observés sur un cycle de 3 ans. Une analyse de variance de ces 10 caractères sur 3 lieux possédant des données complètes (tableau I) fait apparaître un effet considérable des interactions population $x$ lieu dans la variation totale pour 6 des 10 variables : les sensibilités (rouille couronnée, froid), les vigueurs (printemps, été, automne) et la pérennité. Des analyses en composantes principales ont été réalisées, pour chacune de ces 6 variables, sur les termes d'interactions centrés (tableau II). Ces analyses permettent de ramener de 8 à 4 le nombre de lieux à retenir pour décrire 60-70\% de ces interactions en conservant les lieux les plus corrélés aux 2 premières composantes principales (Rodez, Mont-de-Marsan, Bourg-Lastic, le Pin-au-Haras).

Les moyennes ajustées sur 4 lieux pour les caractères stables (alternativité, port, remontaison, date d'épiaison) ou les moyennes phénotypiques dans chacun des lieux retenus pour les autres caractères (sensibilité à la rouille et au froid, vigueur au printemps, en été, en automone, persistance) sont présentées (tableau III) en comparaison avec les valeurs de 6 témoins commerciaux. Bien que les populations spontanées présentent en moyenne des performances inférieures aux témoins, leur large étendue de variation permet aux meilleures d'entre elles d'égaler, et souvent de dépasser les témoins pour la plupart des caractères. Les corrélations entre ces 28 variables sont en général assez faibles, sauf pour certaines mesurées dans le même lieu. Confirmant limportance des interactions, les corrélations pour un même caractère entre différents lieux sont souvent faibles (tableau $\mathrm{V}$ ).

Une classification ascendante hiérarchique à partir de ces 28 variables conduit à choisir une partition en 11 classes, pour laquelle l'inertie interclasse représente plus de $50 \%$ de l'inertie totale. Chaque classe est décrite par la moyenne pour les caractères qui différent significativement de la moyenne générale et par sa localisation géographique. 
Une des classes (10) présente d'aussi bonnes performances que les témoins dans tous les lieux pour tous les caractères, sauf la persistance dans un des lieux. D'autres classes présentent des adaptations plus spécifiques, c'est-àdire de meilleures valeurs seulement dans un site d'évaluation. C'est le cas par exemple du bon comportement à Mont de Marsan (Sud-Ouest) des populations de la région environnante. Les implications évolutives et l'utilité d'une telle typologie pour la gestion des ressources génétiques et l'amélioration des plantes sont discutées.

Lolium perenne $L$ / ressources génétiques / classification multivariable / population naturelle / interaction genotype $x$ milieu

\section{INTRODUCTION}

Apart from cereal crops, grassland is one of the main uses of agricultural land in France, and is predominant in many regions: Brittany, Normandy, and all the hill and mountain regions. Fom $16.310^{6} \cdot$ ha, 12.3 are permanent or "natural" meadow, and around 3.5 are temporary sown meadows.

Perennial ryegrass is one of the grasses most commonly used for sowing or regenerating meadows and its use has increased since 1980: the area sown each year with perennial ryegrass can be estimated at between 60000 ha (Desroches et al, 1984) and 200000 ha (source: seed market). This use may even increase as a consequence of the EEC agricultural policy: limitation of cereal production, encouragement of non agricultural use of land (soil, conservation, sport, etc) milk quota leading to meat price increase.

The main advantage of perennial ryegrass is its high nutritive value compared for example to that of tall fescue and its relatively good persistence compared with Italian ryegrass. However, despite its good adaptation to mild-winter and cool-summer regions such as Normandy, available varieties fail to grow well in more rigorous conditions: heavy frost,. summer heat and drought which are frequent in most French regions where grassland is dominant.

A breeding programme for this species was initiated in 1984 in co-operation with INRA (Institut National de la Recherche Agronomique) and 8 private breeding companies (fig 1). The first step in this programme was the collection of wild populations from all over France and their evaluation for agronomic traits in comparison to control cultivars.

The aim of this collection was primarily to extend the range of available genetic variation, in order to find some material which adapted more readily to most French conditions, including continental and hill areas, than present cultivars.

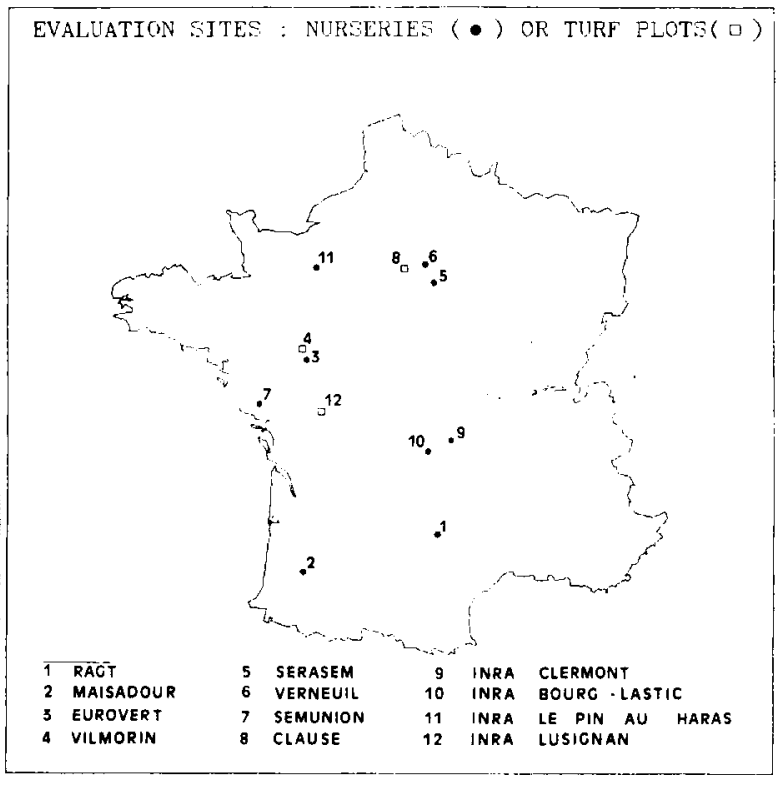

Fig 1. The 12 evaluation sites.

Improved varieties could then be developed either directly from elite populations or after wide hybridization followed by selection (Wilkins, 1986).

This paper describes the results of a multi-site evaluation of this collection for agronomic traits and proposes a classification of populations based on their responses to a range of environments.

\section{MATERIAL AND METHODS}

\section{Collection of populations and experimental designs}

Eleven teams of private breeders or INRA workers collected seed samples throughout the continental French territory during the summer of 1983 and 1984; each year, every team methodically inspected one administrative region and sampled wild ryegrass as regularly as possible, in order to obtain an extensive sample of the possible variations of this natural species. 
From each collecting site, seeds from at least 50 plants were taken from an ecologically homogeneous area of 100 to 1000 square $\mathrm{m}$. These conditions were thought to yield a sample of seeds representative of the original panmictic population (Tyler et al, 1984; Yonezawa, 1985). Information concerning the collection site was taken at the time of collection: general habitat, grassland management, latitude, longitude and altitude. Seeds of all plants were bulked, without balancing the contribution of each plant, then divided into 12 equal amounts for evaluation.

Overall, 226 populations were collected in 1983 and evaluated from 1984 to 1986 ; 321 others were collected one year later and studied from 1985 to 1987 . Wild ryegrass populations were evaluated in 12 different locations in France, either as turf plots or as spaced plant nurseries (fig 1). This paper only deals with spaced plant evaluation.

In each location, seeds from at least 50 plants, from an ecologically homogenous area of 100-1 $000 \mathrm{~m}^{2}$ were sown in the field in spring (April or May) in randomised 3-block design with 6 control cultivars (namely cv Mantilla, Sisu, Préférence, Vigor, Manhattan, Idole) as elementary plots of 10 plants at $40 \mathrm{~cm}$ spacing. The collecting conditions are supposed to provide a sample of seeds representative of the original panmictic population (Jonezawa, 1985; Tyler, 1987). The nurseries were cut 2 or 3 times during the sowing year, allowing diseases to develop, then frequently (every 3 to 4 weeks) in the second year, to simulate rotational grazing. Consequently, all plants were cut the same day at each location whatever their developmental stage. Therefore, most observations were made outside the sexual cycle, eg in early spring and later on in vegetative regrowth. They were finally allowed to flower in the last year to avoid seedling contamination.

Ten traits of agronomic interest were observed during the 3 years, most of them being scored on a visual 1 to 9 scale. These traits are described as follows. During the sowing year: Alternativity ie the ability to produce spikes in the sowing year $(1=$ no spike to $9=$ many ears per plant); growth habit in autumn: $(1=$ erect to 9 = prostate); crown rust susceptibility: $(1=$ resistant to $9=$ heavily damaged).

During the first year after sowing: frost susceptibility ( 1 = no change to 9 = dead); early spring growth $(1=$ weak to $9=$ vigorous); aftermath heading ( $1=$ none to $9=$ many ears and few leaves in the regrowth); summer aspect ( $1=$ dried to $9=$ green and vigorous); autumn regrowth ( $1=$ weak to $9=$ vigorous).

In the second year after sowing: persistence (from 1 = dead to 9 = fully living plant); heading date: (date of ear emergence, from January $1 \mathrm{st}$ ).

\section{Statistical development}

Although the data are initially discrete, their empirical distributions fitted quite well with the gaussian law (except that of alternativity which was very asymmetric. Therefore, we performed multivariate analysis of variance using the model:

$$
\begin{aligned}
X=M U+Y E & +L O+Y E . L O+Y E . L O \cdot B L+P O \\
& +L O \cdot P O+E P S
\end{aligned}
$$

where: $M U$ is the overall average; $Y E$ is the main year effect; $L O$ is the main location effect; YE.LO is the year-by-location interaction; YE.LO.BL is the block (hierarchised) effect; $P O$ is the main population effect; $\angle O . P O$ is the location-by-population interaction; EPS is the residual error.

Because of missing data in many locations, all 10 traits were analysed using data from only 3 locations: 2 (Mont de Marsan), 9 (Clermont-Ferrand) and 11 (Le Pin-au-Haras).

The whole set of populations could not be considered as representative of the same population. For example, for some traits, there were specificities of the different regions for the between populations component of variance, while the error component remained quite stable. Therefore a model (1) (Charmet et al, unpublished data) with fixed effects was used.

\section{Magnitude of interaction effects and consequences for the study}

In model (1) with fixed effects, the expectation of mean squares for PO and LO.PO effects are respectively:

$$
\begin{aligned}
\text { E }\left(\mathrm{MS}_{\mathrm{PO}}\right)= & \sigma_{\mathrm{e}}^{2}+\mathrm{qn}\left(\frac{\sum_{i} p_{\mathrm{i}}^{2}}{p-1}\right) \\
\mathrm{E}\left(\mathrm{MS}_{\mathrm{LO} . \mathrm{PO}}\right) & =\sigma_{\theta}^{2}+n\left(\frac{\left.\sum_{i j} \sum_{i j}\right|_{i j} ^{2}}{(p-1)(q-1)}\right)
\end{aligned}
$$

where $\sigma_{e}^{2}=E\left(M S_{e}\right)$ is the residual variance, $p_{i}$ and $p l_{i j}$ the population and interaction effects, $q$ the number of sites (3), $p$ the number of population (547) and $n$ the number of plants of each population in each site (30). The terms in brackets are the fractions of the variability which could be explained by the PO or LO.PO effect in this specific material, by analogy with the variance components in a random model (Dagnelie, 1970).

In order to appreciate the relative importance of the population main effect, $\mathrm{PO}$, and the population-bylocation interaction, LO.PO, in the total variability of this material, we calculated:

$$
\frac{\sum_{i} p_{i}^{2}}{p-1}=\frac{M S_{P O}-M S_{e}}{90}
$$

$$
\frac{\sum_{i j} \sum_{i} p l_{i j}^{2}}{(p-1)(q-1)}=\frac{M S_{L O . P O}-M S_{e}}{30}
$$

and compared them to each other.

The comparison of these 2 parameters indicated that the population effect is much greater than the interaction for the developmental traits: absence of vernalisation requirement for flowering, growth habit, aftermath heading and date of ear emergence. For 
these traits, phenotypic population means, $\mathrm{MU}+\mathrm{PO}$ (adjusted from year effects) were used.

On the contrary, for the other traits, the contributions of PO and LO.PO are of the same magnitude and therefore population-by-location interactions must be taken into account. Therefore, for all characters apart from the 4 previous ones, interactions were taken into account. Data were computed from 8 (rust susceptibility, frost susceptibility and spring growth) or 7 locations (summer growth, autumn growth and persistence). Data from evaluation sites 5 and 6 were sometimes discarded due to lack of data.

\section{Descriptive analyses and classification}

A principal component analysis was carried out for each trait, using nonstandardised interaction terms for each evaluation site as independent variables. The aim of such an analysis was to summarize the genotype-by-location interaction by a small number of independent (orthogonal) components and to identify the original variables (ie locations). Most correlated to these principal components, which were those accounting for most of the genotype by environment variation (Freeman and Dowker, 1973). This method was quite similar to that proposed by Mandel (1971).

From these analyses, the first 3 principal components account for $60-80 \%$ the interaction variation, and in most cases a single location appears to be highly correlated to each component. Thus, for a given trait, 3 locations explain most of the interaction. Considering all traits leads to the retention of 4 out of 8 evaluation sites as necessary to illustrate the whole range of genotype-by-location interactions: 1: Rodez, 2: Mont-de-Marsan, 10: Bourg-Lastic and 11: Le Pinau-Haras.

Vigour data for these 4 evaluation sites and phenotypic means of flowering without vernalization, growth habit, aftermath heading and date of ear emergence were subjected to principal component analysis. The first 8 components, accounting for $75 \%$ of the inertia, were then used through multivariate hierarchical clustering for grouping the 547 wild populations into more homogeneous classes, using the incremental sum of squares as an aggregation strategy according to Hayward et al (1982). This method allows the data to be cleared of random noise. Consideration of the hierarchical tree suggested that it be cut at the "11 clusters" level. These clusters were characterized by their phenotypic means for the most significant traits. They were firstly compared to the overall mean and secondly to the mean of controls. The location of the clusters is presented on maps.

\section{RESULTS}

\section{Distribution of collected populations}

The first remarkable result can be seen in figure 2: perennial ryegrass (Lolium perenne $L$ ) has

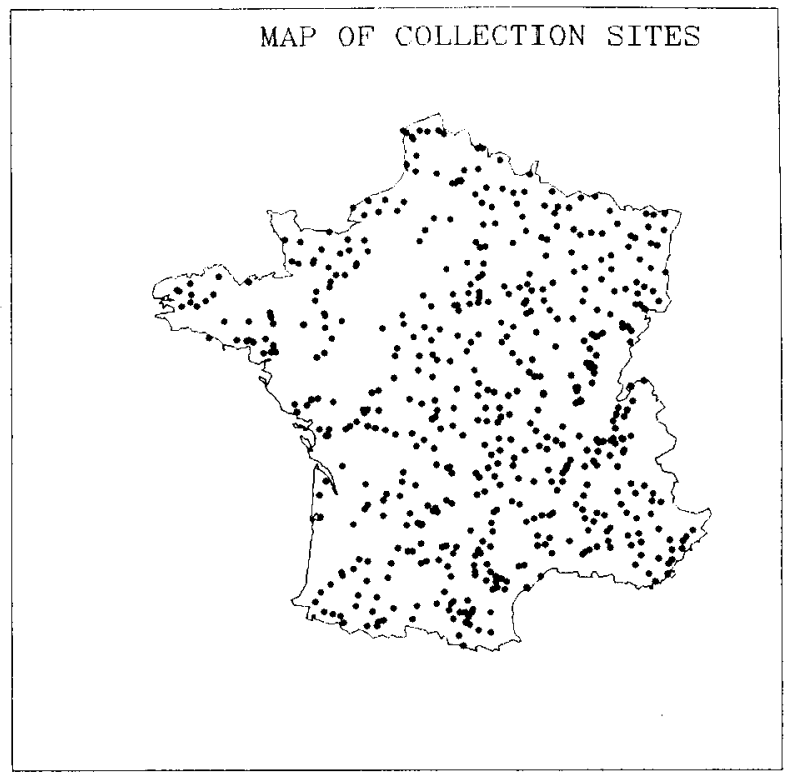

Fig 2. The 547 seed sampling sites of wild populations of perennial ryegrass.

been found everywhere in France, from the north to the mediterranean coast and from sea level to as high as $1800 \mathrm{~m}$ above sea level. Despite the initial advice or random sampling, some areas were under regarding explored, although perennial ryegrass is likely to grow in regions such as the Beauce plain.

However, perennial ryegrass becomes sporadic in the Alps at an altitude higher than $1000 \mathrm{~m}$ : it can only be found in intensively grazed and trodden pastures, as previously reported by Tyler and Jones (1982). Out of 547 true perennial ryegrass populations, 130 originate from grassland (mainly grazed) 262 from roadside or track, and 155 are of miscellaneous or unknown origin.

Unfortunately, the distribution of these types of habitat is not random throughout the area collected, some collectors giving preference to a particular one. This may cause bias when examining the geographic distribution of traits or clusters. This aspect will be discussed in a further paper.

Although discarded from further analyses, Italian ryegrass (Lolium multiflorum Lam) and annual ryegrass (probably $L$ rigidum Gaudin) seed samples have been erroneously picked up, the former mainly in south west France and the latter in the languedocian plain near the mediterranean. Indeed, preference was given to collect perennial ryegrass and confusion occurred only when plants were too ripe, dried and with seeds partially dropped. Nevertheless, the locations of Italian and annual ryegrass and the personal 
communications of several colleagues who collected the plants themselves seem to indicate that in France perennial ryegrass is the most widespread species of the genus Lolium.

\section{Decomposition of variability}

Mean squares of the variance analysis for $10 \mathrm{ag}$ ronomic traits from 3 locations are listed in table I. Most effects appear to be statistically significant for all traits, except the year effect in some cases. The part of the variability due to population main effect on one hand and to the population-by-location interactions on the other hand are shown in the last two columns. The population main effect has a much greater influence than the interactions for the absence of vernalisation requirements for flowering, growth habit, aftermath heading and heading date. Conversely, susceptibility and growth scores show a wide variation caused by the genotype $x$ location interaction.

\section{Principal component analysis}

The results of the 6 principal components analysis carried out on the genotype-by-location interaction for each of the 6 "interacting" traits are summarized in table II. When two locations are highly correlated to the same principal component, both have either similar (same sign) or opposite influence on interactions. In this case, the information they yield is redundant, and only one of the locations can be kept.

However, locations highly correlated to different principal components have independent influence on interaction and must therefore be kept.
According to the trait considered, the first $3 \mathrm{com}$ ponents explain 60 to $77 \%$ of the whole interaction variance.

Since principal component analyses were carried out using the covariance matrix, the locations loaded on the first components are those where interactions are the most important.

For most traits, evaluation site such as Rodez, Mont de Marsan and either Bourg Lastic or Le Pin show independent behaviour in relation to genotype-by-environment interaction. Considering the first 2 components leads us to retain these 4 locations in explaining most of the interaction variation. Other locations such as Clermont or Angers are correlated with the third component for only a few traits and can thus be discarded for the sake of simplicity.

Average and range of variation of adjusted population means $(M u+P o)$ in 3 locations for the stable traits, or phenotypic means of other traits in each of the 4 most interactive locations are listed in table III, allowing 547 wild populations to be compared to the 6 control cultivars.

For a given trait considered alone, wild populations can be found which are less susceptible or more vigorous than the best control, even if the cultivars perform better on average. Figure 3 illustrates some of these traits. Table IV shows the correlation matrix between the 28 traits considered. Although often statistically significant because of the high number of degrees of freedom ( $545 ; 0.05$-threshold is 0.086 ), the correlation cœfficients are generally low, even for the same trait considered in several locations, thus pointing again to the marked influence of populations $x$ location interactions. The highest correlations are found between physiologically-related

Table I. Analysis of variance for 10 agronomic traits from 3 evaluation sites: Mont de Marsan, Clermont-Ferrand, Le Pin au Haras.

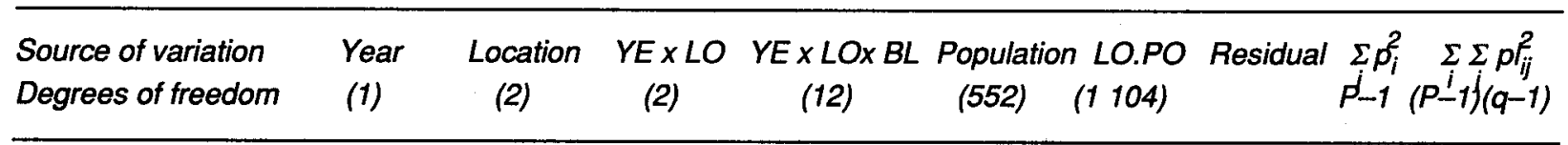

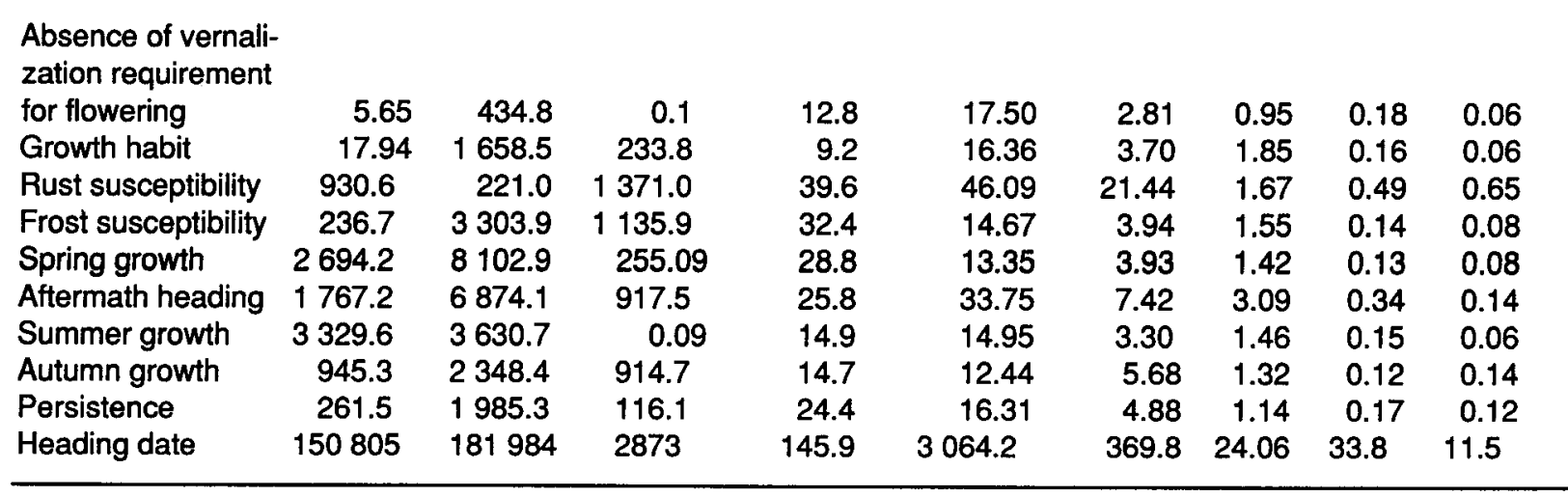


Table II. Correlations between initial variables (ie location) and the first 3 principal components in PCA carried out on population $\times$ location interactions for 6 traits (values of populations are underlined when better than the best controls' values).

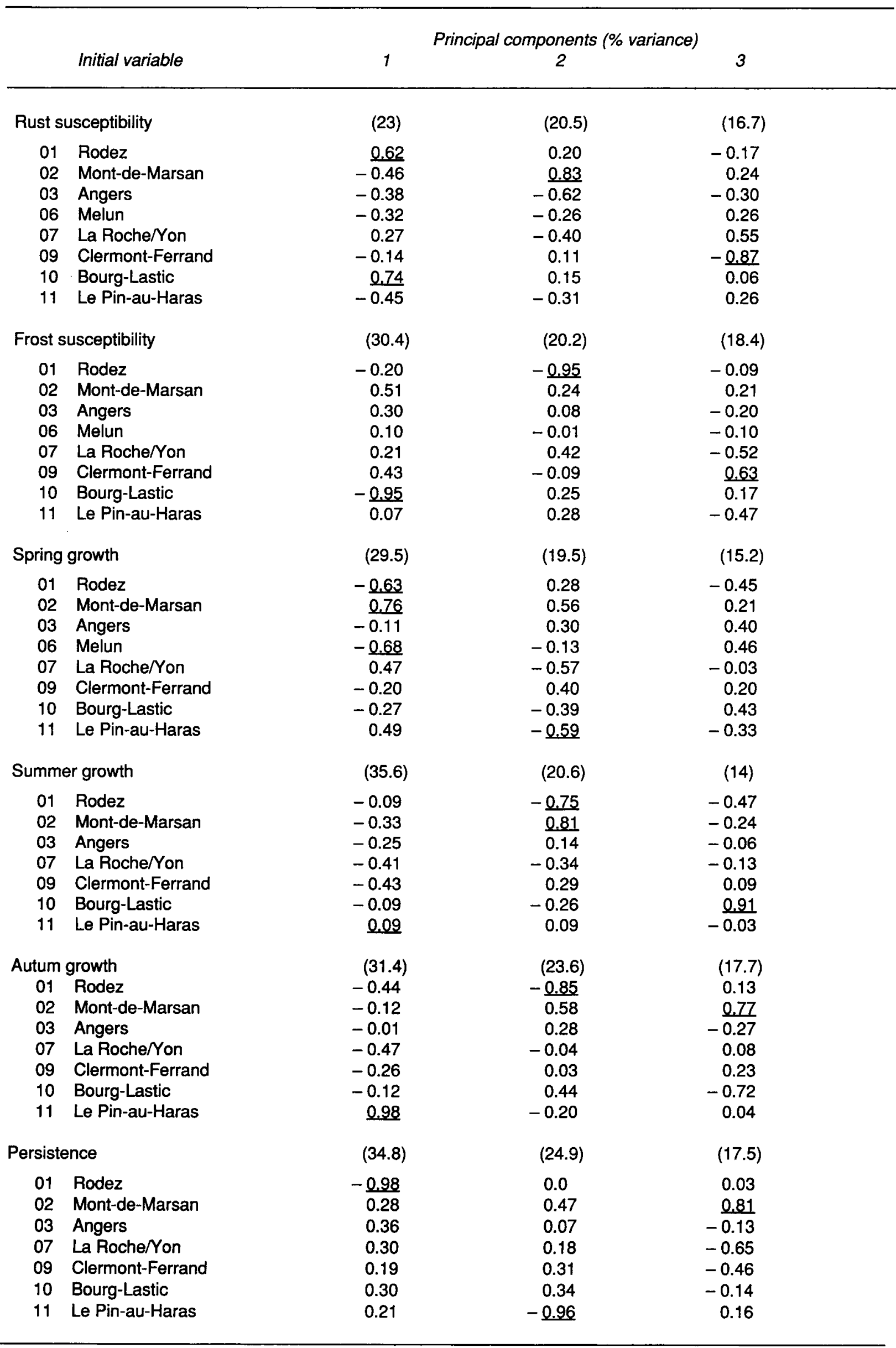


Table III. Mean and range of adjusted population means $M u+P o$ for 4 stable traits, and of phenotypic means for 6 other traits in four locations: comparison of 547 wild populations and 6 control cultivars (values of populations are underlined when better than the best controls' values).

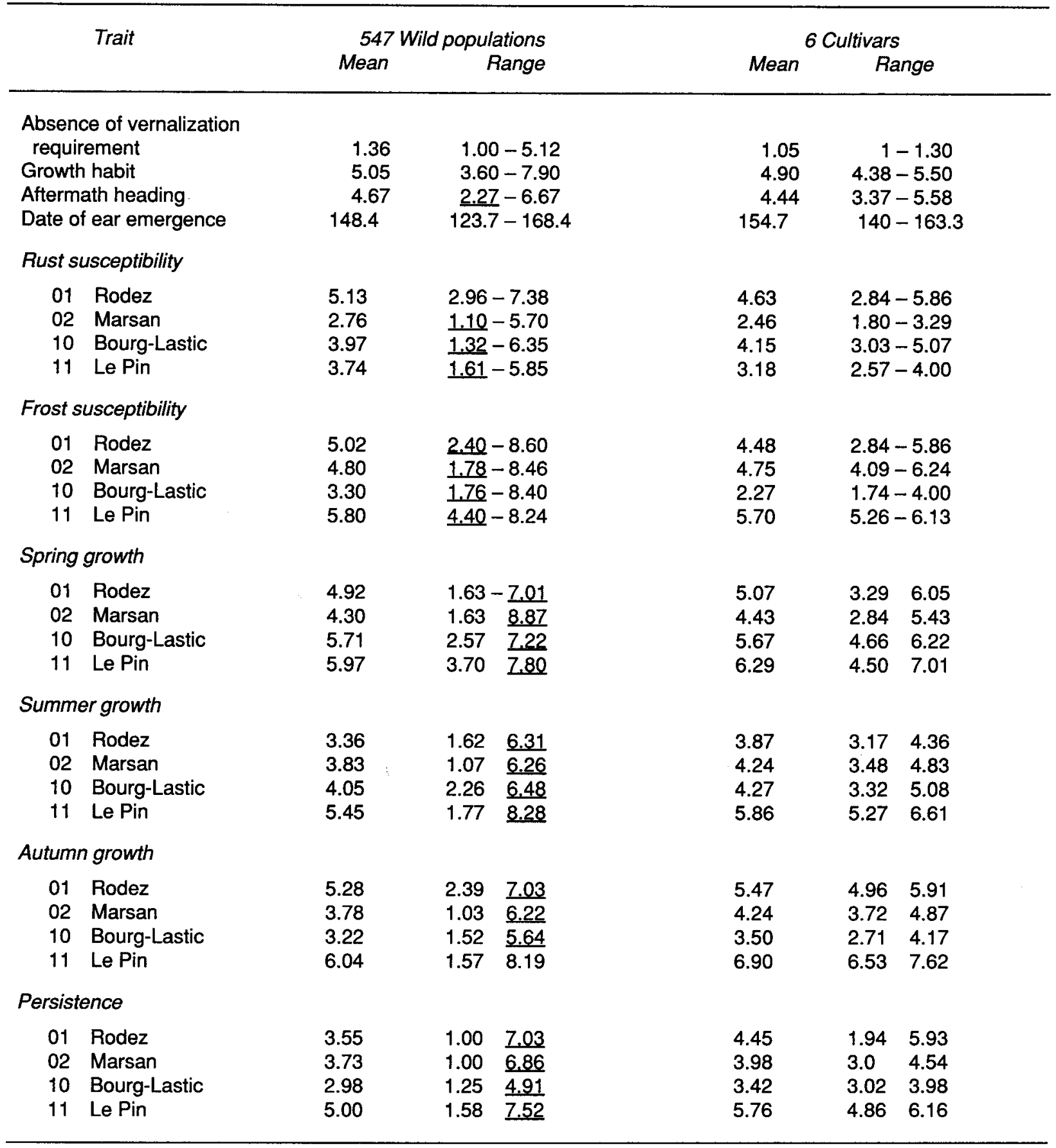

traits such as frost susceptibility and spring growth, or summer and autumn growth when measured in the same location.

\section{Clustering of populations}

Multitrait characterization is necessary to describe the adaptation of the populations to a specific environment, or a range of locations.
For this purpose, a hierarchical clustering method has been applied using data from the 4 locations selected which leads to the tree shown in figure 4. This suggests that the tree should be cut at the 11-cluster level, the between cluster variance on total variance ratio being 0.55 .

The phenotypic means of populations belonging to these 11 clusters are presented in table $V$. They are also compared to the overall mean and the means of cultivars. In table $V$ only the values 

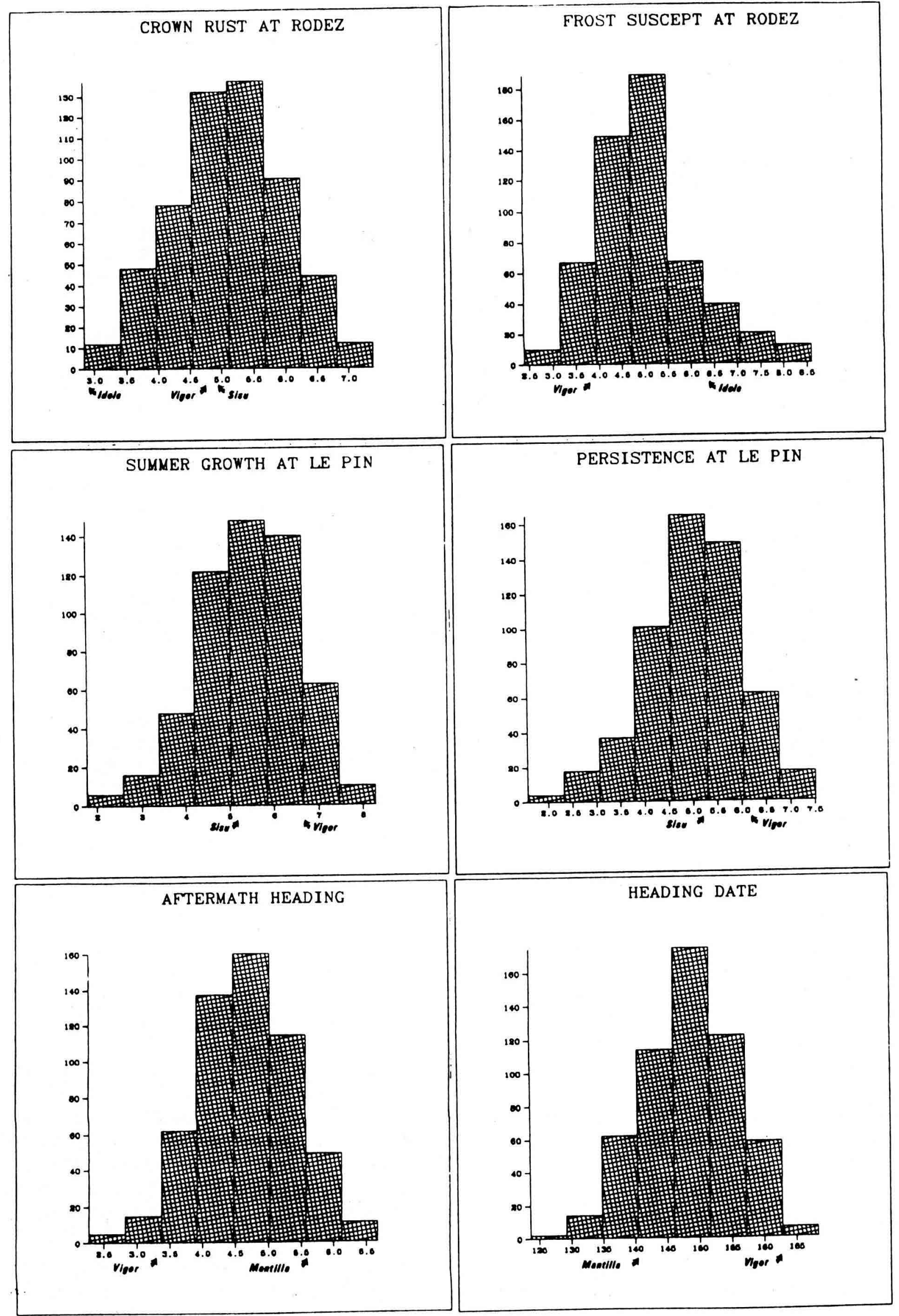

Fig 3. Histograms of distribution of adjusted population means $M u+P o$ for 6 agronomic traits. 


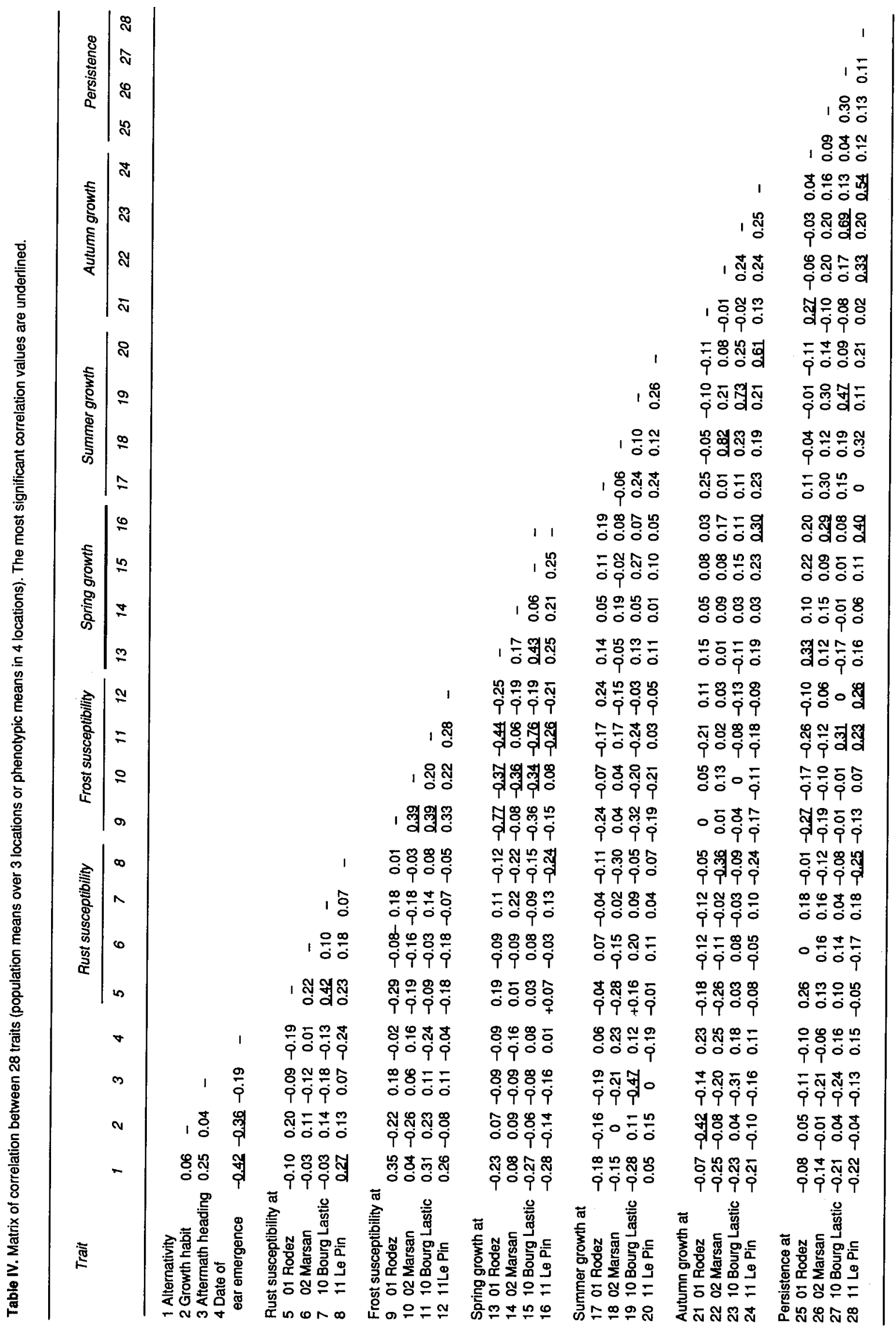




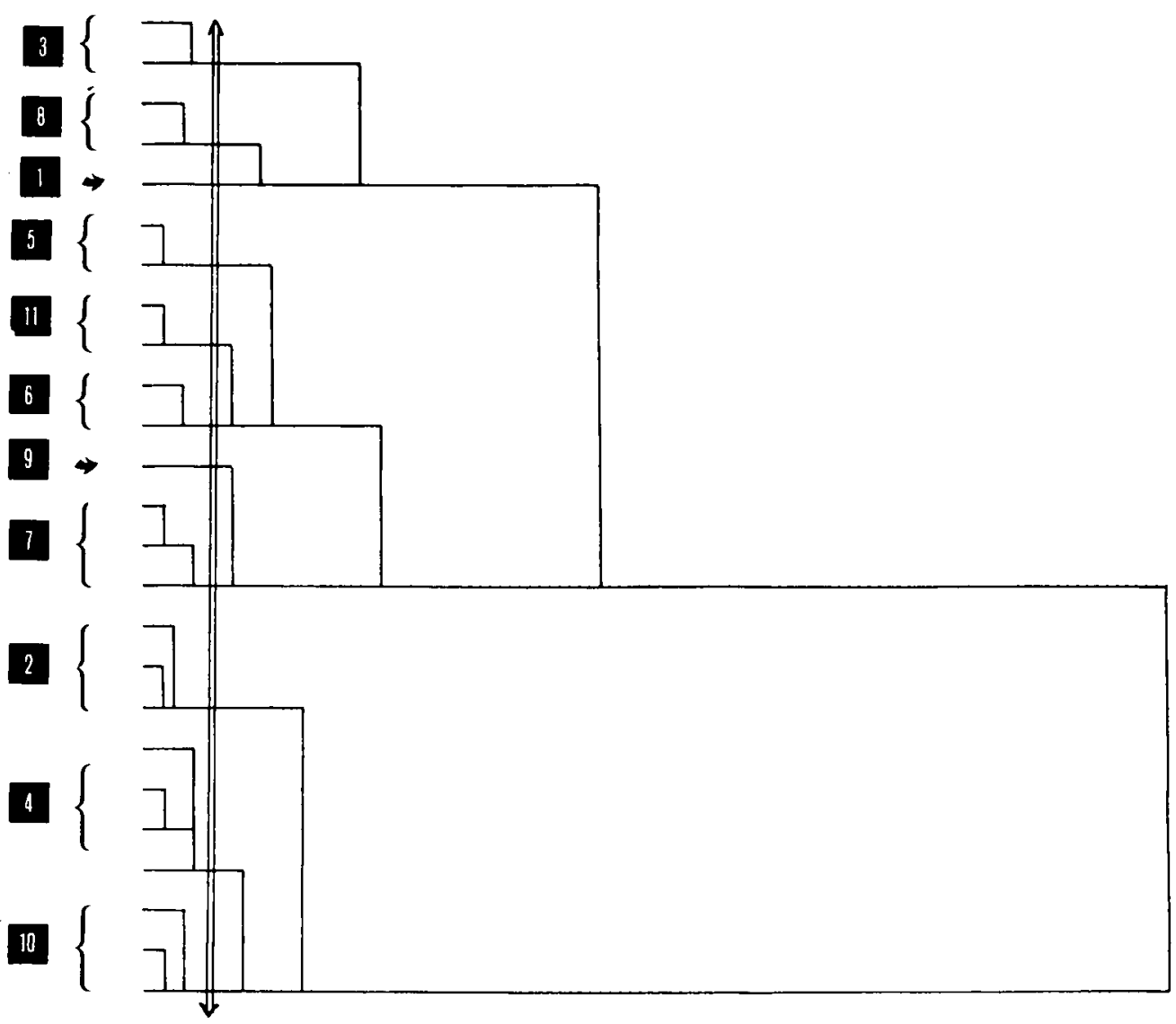

Fig 4. Head of the hierarchical classification tree established using data from 4 locations. Cluster numbers are indicated in squares.

which differed significantly from the overall mean are presented. They are underlined when the mean of the cluster is over the overall mean.

Compared to the overall mean, the populations of some clusters show on average equal or better performance at every location; cluster 10 (except for persistence at Rodez) and cluster 5 and 7 for all traits except crown rust resistance. Confirming the importance of population-bylocation interaction, some clusters include populations performing better than average at one location and worse at another. Populations of cluster 1 are generally below the average for most traits, but show better spring growth and summer aspects at Mont-de-Marsan. Populations of cluster 2 display good autumn growth and persistence at Rodez. Populations of cluster 9 perform well throughout the year at Le Pin.

A summary of the multivariate characterisation of these clusters can be made graphically by again using principal component analysis on the 28 traits described. The first 2 principal components account for only $40 \%$ of the variance because of the large number of traits.
The first component is positively correlated to heading date and negatively to flowering ability without vernalization, aftermath heading and frost susceptibility in the mountain location. Component 2 is mainly explained by frost susceptibilities (negative correlation), spring growth at Rodez and Bourg Lastic and most of the summer growth, autumn growth and persistence. This component could possibly be used as an alternative selection index (Godshalk and Timothy, 1988). Only the clusters correctly represented by projection on the plan of components 1-2 are shown in figure 5 . From the earliest to the latest flowering, clusters 7,5 and 10 show the highest scores for component 2 ("Vigour index"). The position of control cultivars is also given.

The map locations of the 11 clusters are presented in figure 6 . While some clusters have a fairly restricted location within a macroclimatic region, especially clusters 1 and 3 in the southwest or cluster 8 in the mediterranean region, the others generally show a wider distribution through half the country (cluster 10: North and East France). 
Table V. Average of population means for the 11 clusters compared to overall means and means of the cultivars. Values of clusters are underlined when better than overall mean.

\begin{tabular}{|c|c|c|c|c|c|c|c|c|c|c|c|c|c|}
\hline No of population & Cluster 1 & $1 \mathrm{Cl} 2$ & $\begin{array}{l}C / 3 \\
29\end{array}$ & $\begin{array}{r}C / 4 \\
63\end{array}$ & $\begin{array}{l}C / 5 \\
78\end{array}$ & $\begin{array}{r}C / 6 \\
78\end{array}$ & $\begin{array}{c}C / 7 \\
37\end{array}$ & $\begin{array}{l}C / 8 \\
28\end{array}$ & $\begin{array}{l}C l 9 \\
36\end{array}$ & $\mathrm{Cl} 10$ & $\begin{array}{c}C l 11 \\
47\end{array}$ & $\begin{array}{c}\text { Overall } \\
\text { mean }\end{array}$ & $\begin{array}{c}\text { Control } \\
\text { mean }\end{array}$ \\
\hline $\begin{array}{l}\text { Absence vern req } \\
\text { Growth habit } \\
\text { Aftermath heading } \\
\text { Date of ear } \\
\text { emergence }\end{array}$ & $\begin{array}{r}2.79 \\
5.98 \\
4.93 \\
\\
133.8\end{array}$ & $\begin{array}{r}1.10 \\
4.92 \\
4.25 \\
\\
151.4\end{array}$ & $\begin{array}{r}1.50 \\
4.94 \\
4.63 \\
\\
149.3\end{array}$ & $\begin{array}{l}1.11 \\
4.85 \\
4.87 \\
\\
156.8\end{array}$ & $\begin{array}{l}1.16 \\
5.09 \\
4.45 \\
\\
148.0\end{array}$ & $\begin{array}{l}1.36 \\
4.86 \\
5.43\end{array}$ & $\begin{array}{l}1.35 \\
5.72 \\
4.01 \\
137.8\end{array}$ & $\begin{array}{l}2.97 \\
4.90 \\
5.23\end{array}$ & $\begin{array}{l}1.58 \\
5.29 \\
5.11 \\
\\
138.6\end{array}$ & $\begin{array}{l}1.03 \\
4.82 \\
3.92\end{array}$ & $\begin{array}{l}1.28 \\
5.15 \\
4.94\end{array}$ & $\begin{array}{r}1.36 \\
5.05 \\
4.67 \\
\\
148.4\end{array}$ & $\begin{array}{r}1.05 \\
4.90 \\
4.44 \\
154.7\end{array}$ \\
\hline $\begin{array}{l}\text { Rust susceptibility } \\
01 \text { Rodez } \\
02 \text { Marsan } \\
10 \text { Bourg Lastic } \\
11 \text { Le Pin }\end{array}$ & $\begin{array}{l}\text { at } \\
5.51 \\
- \\
4.59 \\
4.21\end{array}$ & $\begin{array}{c}5.29 \\
- \\
- \\
-\end{array}$ & $\begin{array}{l}\frac{4.57}{-} \\
\frac{3.35}{3.51} \\
\end{array}$ & $\begin{array}{l}- \\
- \\
-\end{array}$ & $\begin{array}{c}5.56 \\
3.24 \\
4.17 \\
-\end{array}$ & $\begin{array}{l}\frac{4.68}{2.22} \\
\frac{3.52}{3.58}\end{array}$ & $\begin{array}{c}5.84 \\
3.19 \\
3.99 \\
-\end{array}$ & $\begin{array}{l}- \\
- \\
4.39\end{array}$ & $\frac{-}{2.50}$ & $\begin{array}{c}\frac{4.46}{-} \\
- \\
3.28\end{array}$ & $\begin{array}{c}5.59 \\
- \\
- \\
4.12\end{array}$ & $\begin{array}{l}5.13 \\
2.76 \\
3.97 \\
3.74\end{array}$ & $\begin{array}{l}4.63 \\
2.46 \\
4.15 \\
3.18\end{array}$ \\
\hline $\begin{array}{l}\text { Frost susceptibility } \\
01 \text { Rodez } \\
02 \text { Marsan } \\
10 \text { Bourg Lastic } \\
11 \text { Le Pin }\end{array}$ & $\begin{array}{l}\text { at } \\
- \\
- \\
5.57 \\
6.67\end{array}$ & $\frac{4.81}{-} \frac{1.91}{-}$ & $\begin{array}{l}7.38 \\
6.50 \\
3.89 \\
6.11\end{array}$ & $\begin{array}{l}- \\
5.10 \\
- \\
-\end{array}$ & $\frac{\frac{4.61}{4.36}}{\frac{2.10}{5.61}}$ & $\frac{-}{-} \frac{-}{-}$ & $\begin{array}{l}\frac{3.99}{3.83} \\
\frac{1.89}{5.49}\end{array}$ & $\begin{array}{c}6.27 \\
- \\
2.82 \\
-\end{array}$ & $\begin{array}{c}- \\
- \\
2.83 \\
-\end{array}$ & $\begin{array}{c}- \\
- \\
2.04 \\
-\end{array}$ & $\begin{array}{c}\frac{4.70}{-} \\
- \\
-\end{array}$ & $\begin{array}{l}5.02 \\
4.80 \\
2.30 \\
5.80\end{array}$ & $\begin{array}{l}4.48 \\
4.75 \\
2.27 \\
5.70\end{array}$ \\
\hline $\begin{array}{l}\text { Spring growth at } \\
01 \text { Rodez } \\
02 \text { Marsan } \\
10 \text { Bourg Lastic } \\
11 \text { Le Pin }\end{array}$ & $\begin{array}{l}4.52 \\
4.77 \\
4.47 \\
5.47\end{array}$ & $\begin{array}{l}\frac{5.07}{-} \\
\overline{5.93} \\
\underline{6.15}\end{array}$ & $\begin{array}{c}3.02 \\
4.06 \\
4.74 \\
-\end{array}$ & $\begin{array}{c}- \\
3.88 \\
- \\
5.77\end{array}$ & $\frac{-}{\frac{4.43}{5.92}} \frac{}{6.24}$ & $\begin{array}{l}5.30 \\
- \\
5.84 \\
6.13 \\
\end{array}$ & $\frac{\frac{5.62}{4.57}}{\frac{6.02}{-}}$ & $\begin{array}{c}4.13 \\
- \\
5.20 \\
5.04\end{array}$ & $\begin{array}{l}- \\
- \\
- \\
6.19 \\
\end{array}$ & $\begin{array}{l}- \\
- \\
- \\
-\end{array}$ & $\begin{array}{c}\frac{5.11}{4.13} \\
- \\
5.66\end{array}$ & $\begin{array}{l}4.92 \\
4.30 \\
5.71 \\
5.97\end{array}$ & $\begin{array}{l}5.07 \\
4.43 \\
5.67 \\
6.29\end{array}$ \\
\hline $\begin{array}{l}\text { Summer growth at } \\
01 \text { Rodez } \\
02 \text { Marsan } \\
10 \text { Bourg Lastic } \\
11 \text { Le Pin }\end{array}$ & $\begin{array}{c}2.55 \\
4.28 \\
- \\
6.12\end{array}$ & $\begin{array}{l}3.19 \\
- \\
- \\
4.28\end{array}$ & $\begin{array}{l}-\overline{4.20} \\
3.48 \\
4.78\end{array}$ & $\begin{array}{l}- \\
- \\
-\end{array}$ & $\begin{array}{c}\frac{3.87}{-} \\
4.52 \\
6.29 \\
\end{array}$ & $\begin{array}{c}- \\
- \\
3.62 \\
-\end{array}$ & $\begin{array}{l}\frac{3.63}{3.40} \\
4.68 \\
6.06\end{array}$ & $\begin{array}{l}2.66 \\
3.18 \\
3.12 \\
4.94\end{array}$ & $\begin{array}{c}- \\
- \\
3.73 \\
6.35\end{array}$ & $\frac{\overline{4.63}}{\frac{4.72}{5.86}}$ & $\begin{array}{c}3.16 \\
3.44 \\
- \\
4.76\end{array}$ & $\begin{array}{l}3.36 \\
3.83 \\
4.05 \\
5.45\end{array}$ & $\begin{array}{l}3.87 \\
4.21 \\
4.27 \\
5.86\end{array}$ \\
\hline $\begin{array}{l}\text { Autumn growth at } \\
01 \text { Rodez } \\
02 \text { Marsan } \\
10 \text { Bourg Lastic } \\
11 \text { Le Pin }\end{array}$ & $\begin{array}{l}4.13 \\
3.43 \\
2.90 \\
4.84\end{array}$ & $\begin{array}{c}\frac{5.52}{-} \\
- \\
5.53\end{array}$ & $\frac{\overline{4.08}}{-}$ & $\begin{array}{c}5.14 \\
- \\
- \\
-\end{array}$ & $\begin{array}{c}- \\
- \\
\underline{3.53} \\
\underline{6.66} \\
\end{array}$ & $\begin{array}{c}\frac{5.55}{-} \\
3.02 \\
6.41 \\
\end{array}$ & $\begin{array}{c}4.95 \\
3.33 \\
3.41 \\
-\end{array}$ & $\begin{array}{c}- \\
3.12 \\
2.46 \\
5.19\end{array}$ & $\begin{array}{c}5.01 \\
- \\
- \\
6.64\end{array}$ & $\begin{array}{l}\frac{5.55}{4.61} \\
\underline{3.86} \\
6.77 \\
\end{array}$ & $\begin{array}{l}5.06 \\
3.43 \\
2.99 \\
5.06\end{array}$ & $\begin{array}{l}5.28 \\
3.78 \\
3.22 \\
6.04\end{array}$ & $\begin{array}{l}5.47 \\
4.24 \\
3.50 \\
6.90\end{array}$ \\
\hline $\begin{array}{l}\text { Persistence at } \\
01 \text { Rodez } \\
02 \text { Marsan } \\
10 \text { Bourg Lastic } \\
11 \text { Le Pin }\end{array}$ & $\begin{array}{c}- \\
- \\
2.70 \\
-\end{array}$ & $\begin{array}{c}4.43 \\
- \\
- \\
-\end{array}$ & $\begin{array}{c}2.51 \\
- \\
\frac{3.21}{4.58}\end{array}$ & $\begin{array}{c}3.13 \\
- \\
- \\
-\end{array}$ & $\frac{-}{\frac{4.27}{3.26}}$ & $\begin{array}{c}- \\
3.38 \\
2.65 \\
5.29 \\
\end{array}$ & $\begin{array}{c}4.26 \\
4.26 \\
- \\
-\end{array}$ & $\begin{array}{l}2.77 \\
2.80 \\
2.32 \\
4.12\end{array}$ & $\begin{array}{c}- \\
- \\
- \\
5.36\end{array}$ & $\begin{array}{c}3.20 \\
- \\
3.27 \\
6.00\end{array}$ & $\begin{array}{c}- \\
- \\
2.77 \\
4.06\end{array}$ & $\begin{array}{l}3.55 \\
3.73 \\
2.98 \\
5.00\end{array}$ & $\begin{array}{l}4.45 \\
3.98 \\
3.42 \\
5.76\end{array}$ \\
\hline
\end{tabular}

\section{DISCUSSION}

\section{Other collections of ryegrass populations}

Perennial ryegrass has been one of the grass species most studied in the last decades in temperate climates, mainly in Europe and New Zealand for forage use. Numerous collections of natural populations have been described in the literature. The following list is probably not exhaustive: Italy (Lorenzetti and Piano, 1974), Yu- goslavia (Gracan, 1964), Turkey (Elci, 1979), Romania (Kovacs, 1980), Poland (Lutynska et al, 1975; Osinsky, 1979), Soviet Union (Pavlik, 1967; Sutova, 1968), Germany (Paul, personal communication) and New Zealand where ryegrass was introduced by the pioneers in the last century (Suckling and Forde, 1978). Particular mention should be made of the work of the Welsh Plant Breeding Station (WPBS, UK) since the sixties. This institute, now in charge of the European genetic resources databank for ryegrass and white clover, previously collected 


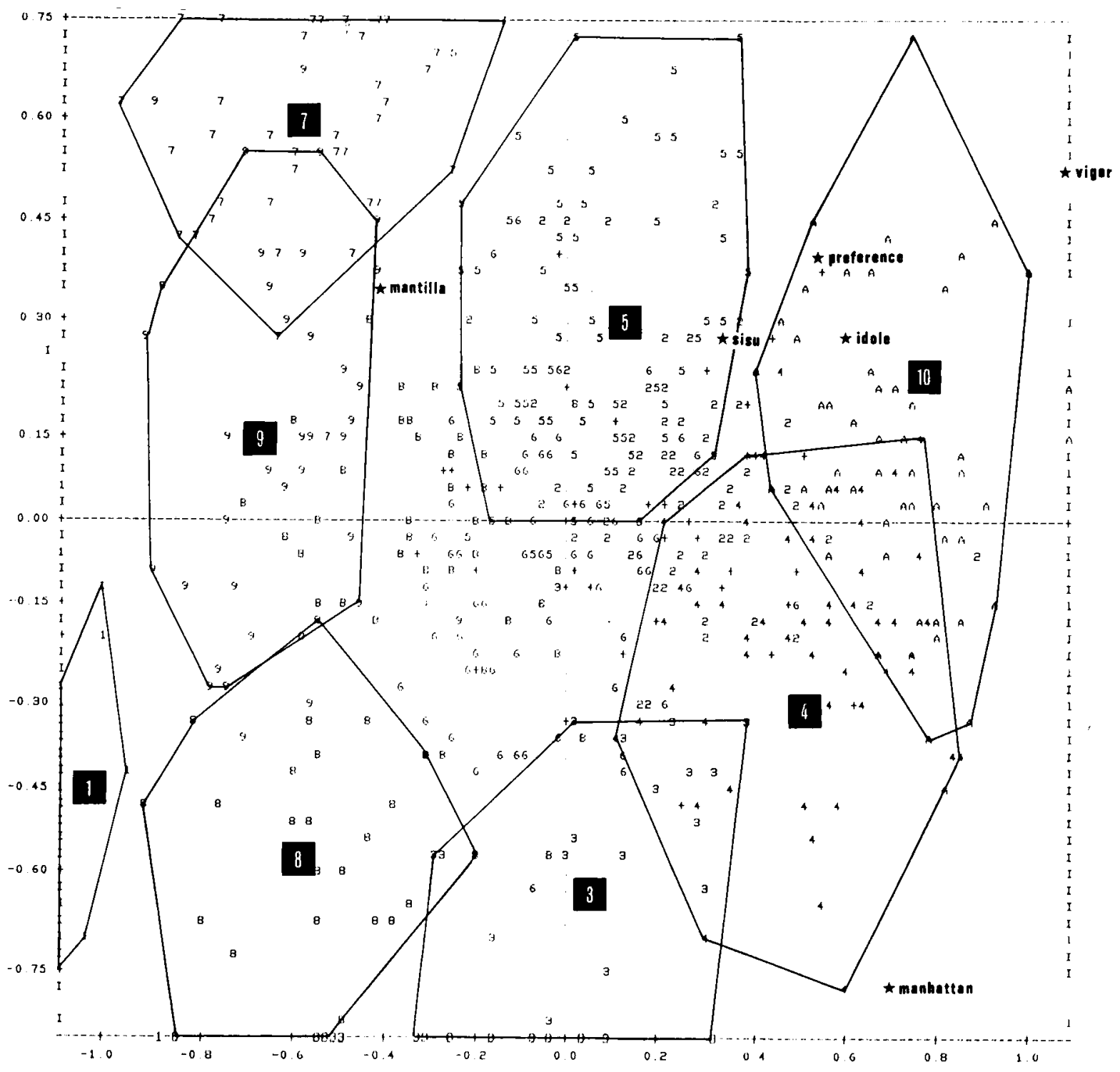

Fig 5. First plan of the principal component analysis carried out on 28 traits with projection of some cluster limits. Component 1 as $x$ axis-component 2 as $y$ axis.

Welsh populations (Breese, 1963) which have been used extensively for genetic studies (Hayward, 1967; Hayward and Breese, 1966, 1968). They continued with the main objective of extending European coverage by collections in Iberia, south eastern France, Scandinavia and northern France and Switzerland (Tyler and Williams, 1972), the only collection in France previously reported, Italy (Tyler and Chorlton, 1978), Romania (Tyler et al, 1981), Switzerland (Chorlton and Rhodes, 1983), Bavaria and Austria (Tyler and Thomas, 1987). Endangered habitats in Wales (Tyler et al, 1984) as well as water and flood meadows in southern England (Tyler et al, 1981) were also collected for conservation.
As reviewed by Tyler (1979), the collection strategy of the WPBS was largely determined by considerations of macroclimate which resulted in an extensive sampling over considerable distances, with the aim of predicting the most likely climates that would provide the required growth attributes: winter or early spring growth in mildwinter climate, and winter hardiness in relation to winter temperature (Lorenzetti et al, 1971). However, ecotypic differentiations caused by contrasting microenvironments have been found (Tyler and Chorlton, 1976) and suggested intensive collections with subsampling in every ecologically differentiated habitat. Therefore, the collections made by the WPBS generally em- 
CLUSTER 1

CLUSTER 3
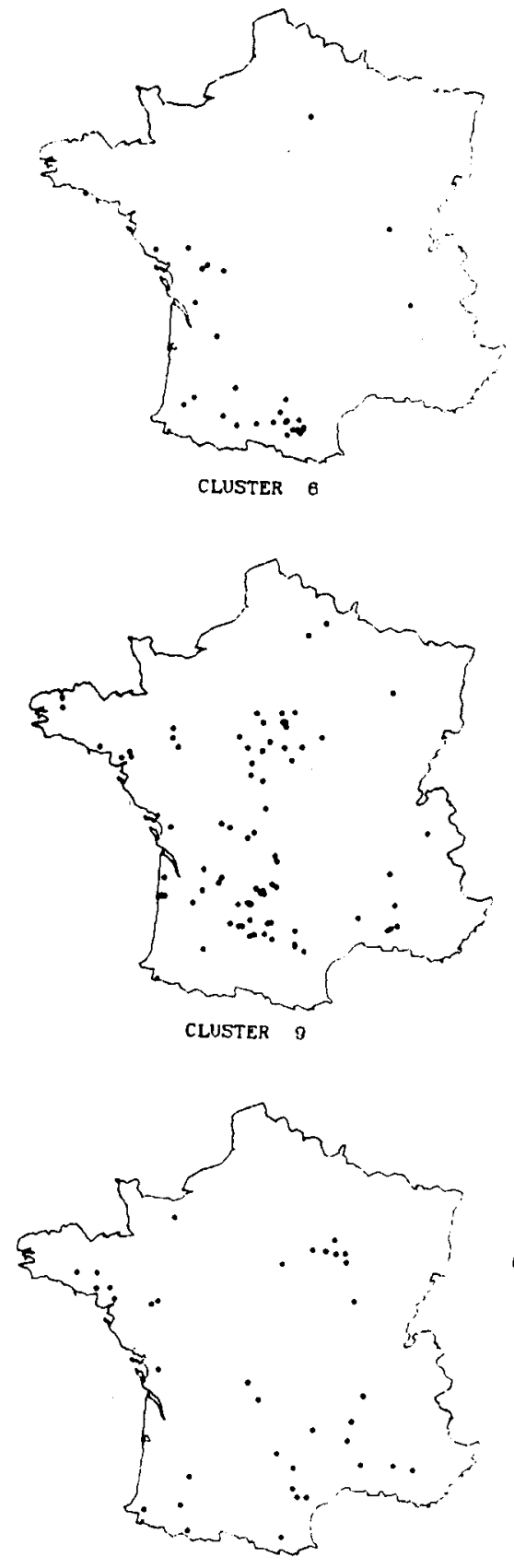

Fig 6. Population sites on the 11 clusters.

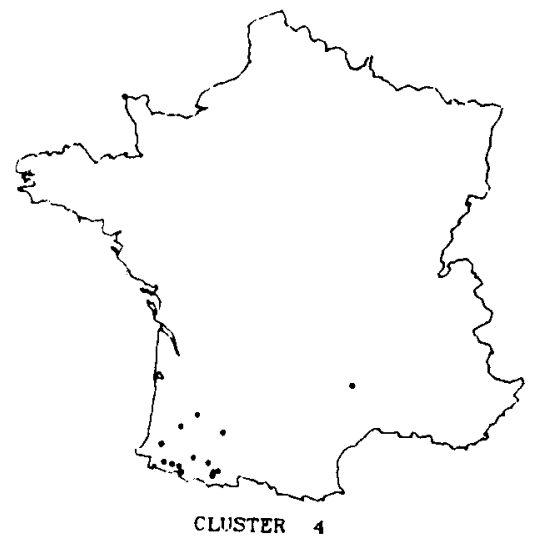

CLUSTER 2
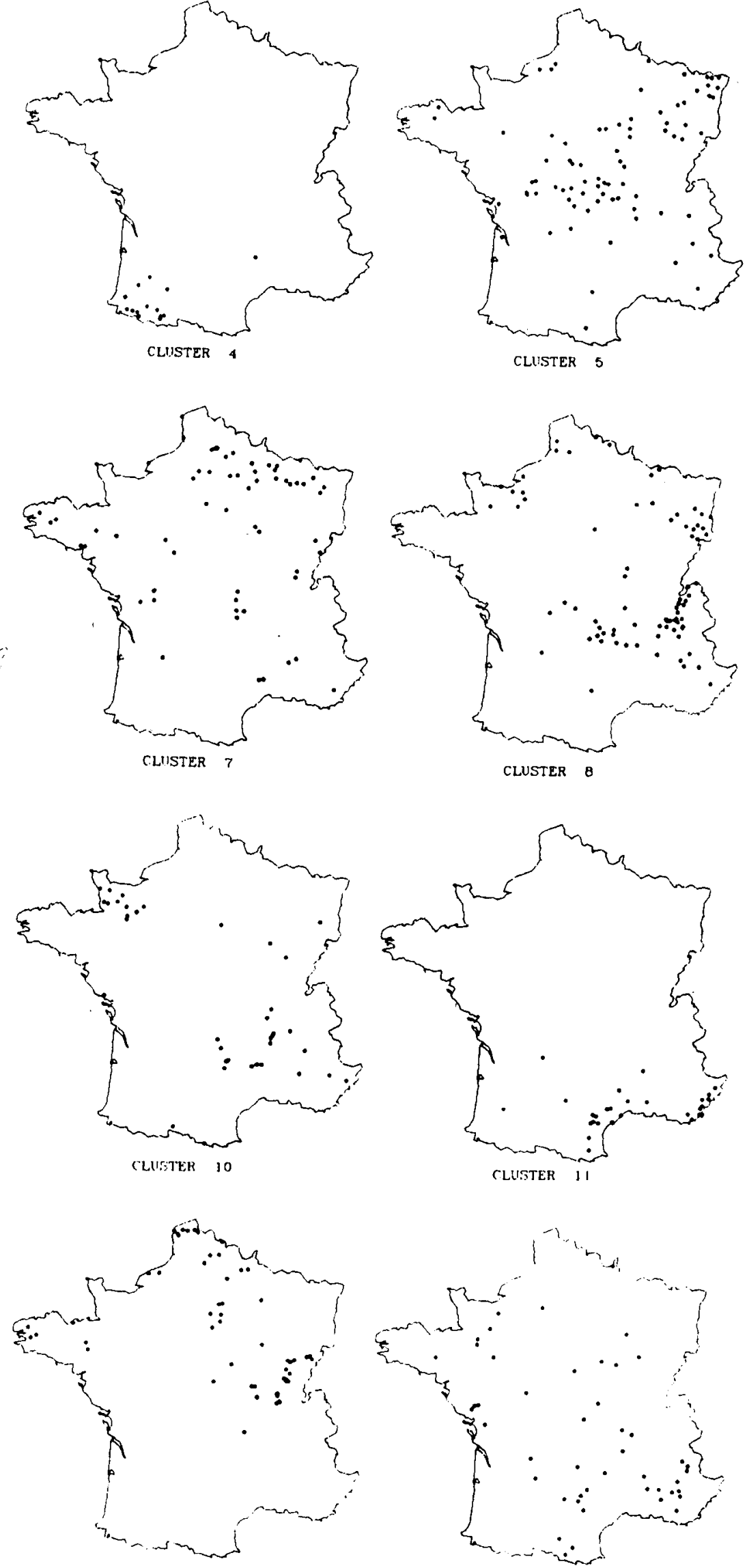
phasised the quality of the samples (amount of information concerning past history, management and vegetative propagules in order to avoid genetic drift caused by unequal flowering) rather than their number.

When perennial ryegrass breeding began 30 years later, French breeders made another choice: to collect as many populations as possible in a short time, without having a preconceived idea concerning region, type of habitat etc. This strategy led us to collect seeds and often forced us to sample roadsides in order to save time. We can reasonably assume that the former restriction is not too serious: the grazing intensity is moderate in most farms in France which, combined with the warmer climate, generally allows enough plants to flower and seeds to be obtained to prevent genetic drift, even in pastures. The consequences of sampling many roadsides rather than grasslands will be analysed in a further study. Unfortunately, data concerning management practices and fertilisation level are often missing and are therefore difficult to take into account.

\section{Limits of the present evaluation}

Another aspect of this study can certainly be criticised: the evaluation of the collection for forage traits was made in terms of spaced plants only, while evaluation at the Welsh plant breeding station generally involved spaced plant nurseries for flowering traits and individual susceptibilities, sward plots for yield under cutting or even grazing management, and tests in glasshouse or controlled environments, eg for freezing tolerance (Humphreys and Eagles, 1988) or in vitro digestibility (Tyler and Hayward, 1982).

Indeed, spaced plant evaluation has been reported to be of little value for traits such as dry matter yield, which is not reliable with yield in sward conditions (Lazenby and Rogers, 1964; Wright and do Valle Ribeiro, 1973). In selection experiments for yield of spaced plants, Hayward (1983) obtained a slight positive response on yield again evaluated in spaced plants, but Hayward and Vivero (1984) failed to find any progress on yield measured in swards. Some results, however, are more encouraging: Valle Ribeiro (1970) found that dry matter yield of spaced plants at relatively high density $(0.24 \mathrm{~m} \mathrm{x}$ $0.24 \mathrm{~m}$ apart) agreed with data obtained from swards. Sedcole and Clements (1973) in genotype $x$ spacing interaction studies, found high correlations between general combining ability at large and narrow spacing. Davies and Snaydon (1989) confirmed that only weak correlations exist between the yield of populations as spaced plants and their yield in sward, and that the relative performance of populations is considerably affected by site conditions; population evaluation thus requires several environments.

We must therefore be aware of the limits of spaced plant evaluation. This method is, however, only suitable for very large collections, and/or when very few seeds are available. Since yield of spaced plants has proved to be of limited utility, visual recording of vigour may, however, provide suitable ranking of population for diseases or stress susceptibility, ability for seasonal growth and, as another advantage, it is not so timeconsuming (Tyler and Jones, 1982).

\section{The value of the French wild material}

Bearing in mind all these limitations, what conclusions can be drawn from this preliminary evaluation of a comprehensive collection of French perennial ryegrass?

As reported in most publications, the wild populations of perennial ryegrass collected in France show a much wider range of variations than do current cultivars used as controls. Although wild populations show, on average, worse agronomic performances than cultivars, their wider range of variations allows the best ones to have interesting values for some traits: rust resistance or winter hardiness, specific ability to grow well in a particular region. These "elite" populations, when identified, could be used directly as cultivars, or after a simple mass selection of the surviving plants in nurseries, as proposed by Wilkins and Lovatt (1984).

Such cases of better adaptation of some local populations compared to that of foreign cultivars have been described by Lorenzetti and Piano (1974) for central Italian ecotypes tested at Perugia, Spatz et al (1987) for a German population, Chernyauskas et al (1986) in the Soviet Union. An example is given in our collection by the good behaviour at Mont de Marsan of the populations from the surrounding region of Mont de Marsan (cluster 1), and, to a lesser extent, by the fairly good growth of the populations from the surroundings of Le Pin and Bourg Lastic (cluster 5), which were unfortunately quite susceptible to rust. 
The best elite populations are commonly found in cluster 10, which shows a general adaptation to rust resistance, winter hardiness, summer and autumn growth (but not spring growth) at all of the 4 evaluation sites found to be indicative of most of the genotype-by-location interaction encountered in France. While populations of cluster 10 are late flowering, non alternative and present little aftermath heading, they undoubtedly represent the most promising material for short-term breeding of new varieties for grazing with wide adaptation to French conditions.

The data for the 547 natural populations have been organized in a database, which will be used by plant breeders or private companies for choosing their basic material, for example by index selection as proposed by Humphreys and Jones (1985). This database includes passport data in the form required by IBPGR (1985). The evaluation data presented here are the original data, according to the scale described in Material and Methods. To meet the requirements of IBPGR (mean of controls fixed to 7) simply needs a transformation by adding or subtracting a constant.

\section{Multivariate classification and genetic resources management}

Evidently, the multiplication and conservation of representative populations of these clusters will be given priority.

However, even populations showing interesting levels for only one or 2 traits can be used in breeding programmes, for example through wide hybridisation followed by recurrent selection (Wilkins, 1986). Heterosis in interpopulational hybrids has been described by Foster (1973), Wilkins and Lovatt (1984), Hayward et al (1985), especially when crossing populations showing complementary patterns of growth.

Therefore, to ensure progress in long-term breeding the conservation of a wide range of genetic variability is required, even if it does not seem very useful in the short-term. However, for widespread indigenous species such as Lolium perenne, saving all natural populations is obviously unattainable. Preference must be given to the most promising ones or to those living in endangered habitats. For the others, it would be profitable to set up a core collection, including 10 to $20 \%$ of the whole collection. Multiplication will need to be carried out on and a comprehensive evaluation will have to be made of this corecollection (Brown, 1989).

Multivariate clustering could provide a scientific basis to this concept of core collection: sampling of populations in every cluster should be made in order to maximize the variability within the subsample of the population retained.

To this aim, Falcinelli et al (1988) classified Italian germplasm of perennial ryegrass but they used data from one location only. In the same way, Veronesi and Falcinelli (1988) recognised genetic erosion in Italian germplasm of tall fescue. Hayward et al (1982) first applied multivariate analysis to the seasonal growth pattern of a collection of Lolium multiflorum for the recognition of adaptation. Their clustering took into account genotype $x$ environment (here cut) interactions; and the groups obtained could be related to the ecological situation from where the populations were derived.

Applied to a multitrait and multisite set of data, hierarchical clustering of a large collection of French populations was reduced to 11 groups, which maintained $55 \%$ of the total variation as between-cluster variation.

In addition to its usefulness for managing genetic resources, such a classification may also indicate the choice of parent genotypes for interpopulational hybridisation. Since populations from different clusters have contrasting and possibly complementary characteristics, crossing them may increase the chance of finding high heterosis levels or useful recombinants, as shown by Peeters and Martinelli (1989).

The construction of a broad base population from a cluster and its improvement by recurrent selection would require the knowledge of genetic parameters within it, especially when using multivariate (multitrait and/or multisite) selection indices as proposed by Humphreys and Jones (1985). Further experiments are planned in this respect.

The relationships between the agronomic traits of the populations and ecological features, ie macroclimatic variations and microenvironments at the site of origins have been reported (Tyler and Chorlton, 1979; Breese and Tyler, 1986) and will be examined in a further study. The analysis of the spatial variation of agronomic features by means of geostatistic methods may provide a way for a better understanding of ecotype differentiation in perennial ryegrass.

Although still at a phenotypic level, the multivariate description and classification proposed in 
this paper could be beneficial to the breeder as basic information on indigenous material and to the scientist as a starting point for more fundamental research on plant evolution and differentiation.

\section{ACKNOWLEDGMENTS}

The authors wish to thank their colleagues from private companies for providing evaluation data and for helpful discussions and comments: Dr Chosson (RAGT), Dr Meunier (Mäisadour), Dr Debrand (Eurovert), Dr Fouche (Serasem), Dr Flore (Verneuil), D Trouvat (Semunion). This co-operative work was supported by the French Ministry of Agriculture.

\section{REFERENCES}

Breese EL (1963) Population studies in ryegrass. In: Annual Report. Welsh Plant Breeding Station 1962. Aberystwyth, UK, 23-24

Breese EL, Davies WE (1970) Sources of genetic variability I. Plant introductions. In: Jubilee Report Welsh Plant Breeding Station 1919-1969 Aberystwyth UK, 16-18

Breese EL, Tyler BF (1986) Patterns of variation and the underlying genetic and cytological architecture in grasses with particular reference to Lolium. In: Infraspecific Classification of Wild and Cultivated Plants (Styles BT, ed) Oxford, UK, 53-69

Brown AHD (1989) The case for core collection. In: The Use of Plant Genetic Resources (Brown AHD, Frankel OH, Marshall DR, Williams JT, eds) Cambridge, UK

Chernyauskas Gl, Zhidonite YA, Lyamyazhene NG (1986) Evaluation and utilization of initial material in breeding grasses. Sb Nauchn Tr Priklad Botan, Gen Selekt 103, 51-57 (in Russian)

Chorlton KH, Rhodes I (1983) Collecting Lolium, Festuca and Trifolium in Switzerland. Report, Welsh Plant Breeding Station 1982. Aberystwyth UK, 3334

Dagnelie P (1970) Théorie et méthodes statistiques. Applications agronomiques. Vol II. Gembloux, Belgium

Davies TM, Snaydon RW (1989) An assessment of the spaced-plant trial technique. Heredity 63, 37-45

Desroches P, Gayraud P, De Ponteves B (1984) Données nouvelles concernant les prairies cultivées. Fourrages 100, 129-160

Elci S (1979) Native Turkish forage legumes and grasses in agriculture. In: Broadening the Genetic Base of Crops. Proc Conf, 3-7 July 1978, Wageningen The Netherlands, 159-160

Falcinelli M, Veronesi F, Lorenzetti S (1988) Evaluation of an Italian germplasm collection of Lolium perenne $L$ through a multivariate approach. In: Nat- ural Variation and Breeding for Adaptation. Proc EUCARPIA Fodder Crops Section Meeting, September 22-24, 1987 Lusignan, France

Foster CA (1973) Interpopulational and intervarietal F1 hybrids in Lolium perenne performance in field sward conditions. J Agric Sci 80, 463-472

Freeman GH, Dowker BD (1973) The analysis of variation between and within genotypes and environments. Heredity 30, 97-109

Goldshalk EB, Timothy DH (1988) Factor and principal component analyses alternative to index selection. Theor Appl Genet 76, 352-360

Gracan R (1964) The biological and agronomic characteristics of indigenous forms of $L$ perenne. Bull Sci Cons Acad Yougos/9, 171-172

Hayward MD (1967) The genetic organisation of natural population of Lolium perenne. II. Infloresence production. Heredity 22, 105-116

Hayward MD (1983) Selection for yield in Lolium perenne. I. Selection and performance under spaced plant conditions. Euphytica 32, 85-95

Hayward MD, Breese EL (1966) The genetic organisation of natural populations of Lolium perenne. I. Seed and seedling characters. Heredity 21, $287-$ 304

Hayward MD, Breese EL (1968) The genetic organisation of natural populations of Lolium perenne. III. Productivity. Heredity 23, 357-368

Hayward MD, Vivero JL (1984) Selection for yield in Lolium perenne. II. Performance of spaced plant selections under competitive conditions. Euphytica 33, 787-800

Hayward MD, De Lacey IH, Tyler BF, Drake DW (1982) The application of pattern analysis for the recognition of adaptation in a collection of Lolium multiflorum population. Euphytica 31, 383-396

Hayward MD, Mc Adam NJ, Eissa MM, Kearsey MJ, Devey $F$ (1985) Heterosis in interpopulation hybrids of perennial ryegrass. In: Report Welsh Plant Breeding Station 1984. Aberystwyth, UK, 32-33

Humphreys MO, Jones JL (1985) Genetic correlations and multitrait selection. In: Report, Welsh Plant Breeding Station 1984. Aberystwyth, UK, 35-36

Humphreys MO, Eagles CF (1988) Assessment of perennial ryegrass (Lolium perenne $L$ ) for breeding. I. Freezing tolerance. Euphytica 38, 75-84

IBPGR (1985) Forage Grass Descriptors (Tyler BF, Hayes JD, Davies WE, eds). EEC, Brussels/IBPGR Rome, 1-30

Kovacs AJ (1980) Chorology of nature sources of germplasm of perennial forage grasses. 1. Lolium perenne L. Probl de Gen Teor Apa 12, 430-454 (Ro)

Lazenby A, Rogers AH (1964) Selection criteria in grass breeding. II. Effect on Lolium perenne of differences in population density, variety and available moisture. J Agric Sci Camb 62, 285-298

Lorenzetti F, Piano E (1974) Genetic control of agronomic characters and ecotype selection in Lolium perenne L. Genetica Agraria 28, 60-78 
Lorenzetti F, Tyler BF, Cooper JP, Breese EL (1971) Cold tolerance and winter hardiness in Lolium perenne. I. Development of screening techniques for cold tolerance and survey of geographical variation. J Agric Sci Camb 76, 199-209

Lutynska R, Kostuch R, Lipinski J (1975) Plant associations of meadow and pasture as sources of initial material for grass breeding. Biul Inst Hodowli Aklimat Roslin 126/127, 39-42 (in Polish)

Mandel J (1971) A new analysis of variance model for non-additive data. Technometrics 13, 1-18

Osinski B (1979) Variability of characters of four forage species - cocksfoot (Dactylis glomerata), meadow fescue (Festuca pratensis), timothy (Phleum pratense), and perennial ryegrass (Lolium perenne). Hodowla Roslin, Aklimat Nasiennictwo 23, 197-29 (in Polish)

Pavlik ZJ (1967) An evaluation of wild forms and local and bred varieties of Lolium perenne. Seleke Semenovod Mezved Sborn 7, 37-43 (in Russian)

Peeters JP, Martinelli JA (1989) Hierarchical clustering analysis as a tool to manage variation in germplasm collection. Theor App/ Genet 78, 42-48

Sedcole JR, Clements RJ (1973) Studies on genotype $x$ spacing interactions for herbage yield using a modified diallel analysis. J Agric Sci 80, 97-104

Spatz G, Schroppel H, Bauer J (1987) The autochtonous ryegrass population Lempten, its yield potential and persistence in comparison with bred varieties. Wirtschaftseigene Futter 33, 248-261 (in German)

Suckling FET, Forde MB (1978) Genetic resources in high rainfall hill pasture of New Zealand. I. Collection of ryegrass, browntop, and white clover. NZJ Agric Res 21, 495-508

Sutova ZP (1968) Agrobiological study of meadow grass, perennial ryegrass and Agrostis alba in the Leningrad area. Bull Appl Bot Genet PI Breed 38 106-117 (in Russian)

Tyler BF (1979) Collections of forage grass in Europe. In: Broadening the Genetic Base of Crops. Proc Conf Wageningen, Netherlands, 3-7 July 1978, 8389

Tyler BF (1987) Collection, characterisation and utilization of genetic resources of temperate forage grass and clover. IBPGR Training Courses, Lecture Ser 1 , $66 \mathrm{p}$

Tyler BF, Williams IG (1972) A collection of Lolium and Festuca in western Europe. In: Report, Welsh Plant Breeding Station 1971. Aberystwyth, UK, 18-19

Tyler BF, Chorlton KH (1976) Ecotypic differentiation in Lolium perenne populations. In: Report, Welsh Plant Breeding Station 1975. Aberystwyth, UK, 1415

Tyler BF, Chorlton KH (1978a) A Lolium and Festuca plant collecting expedition to northern ltaly. Rev Agron 12, 181-190
Tyler BF, Chorlton KH (1978b) Characterisation of perennial ryegrass ecotypes from eastern France and Switzerland. In: Report, Welsh Plant Breeding Station, 1978. Aberystwyth, UK, 43-46

Tylber BF, Chorlton KH (1979) Characterisation of perennial ryegrass ecotypes from Eastern France and Switzerland. Rep Welsh Plant Breed Stn, Aberystwyth, 43-46

Tyler BF, Hayward MV (1982) A sampling technique for assessing digestibility of Italian ryegrass populations. Euphytica 31, 349-355

Tyler BF, Jones EL (1982) Evaluation of genetic resources in relation to breeding objectives and varietal assessment. Proc EUCARPIA Fodder Crop Section Meeting, Aberystwyth, UK, 1982, 148-162

Tyler BF, Thomas H (1987) Extending genetic resources. Plant Collections. In: Report, Welsh Plant Breeding Station 1986. Aberystwyth UK, 103-105

Tyler BF, Chorlton FK, Thomas ID (1981) Plant collection in Romania and southern England. In: Report, Welsh Plant Breeding Station, 1980. Aberystwyth UK, 44-46

Tyler BF, Chorlton KH, Thomas ID (1984) Characterisation of collected $L$ perenne populations. In: $R e$ port, Welsh Plant Breeding Station 1983. Aberystwyth, UK, 29-32

Valle Ribeiro AM (1970) Assessment and selection of initial material for breeding perennial ryegrass (Lolium perenne L). J Agric Sci Camb 74, 433-444

Veronesi F, Falcinelli M (1988) Evaluation of an Italian germplasm collection of Festuca arundinacea Schreb through a multivariate analysis. Euphytica $38,211-220$

Wilkins PW (1986) Breeding for yield in perennial ryegrass by wide hybridisation and recurrent selection. In: New Methods, Techniques and Applications in Fodder Crop Breeding. Rep EUCARPIA Fodder Crop Section Meeting, Svalöf, Sweden 25-30

Wilkins PW, Lovatt JA (1983) Seasonal yield, total yield and persistency in perennial ryegrass. In: $R e$ port, Welsh Plant Breeding Station, 1982. Aberystwyth, UK, 36

Wilkins PW, Lovatt JA (1984) Improving yield of ryegrass under combined conservation/simulated grazing managements. In: Report, Welsh Plant Breeding Station, 1983. Aberystwyth, UK, 33-34

Wright CE, Do Valle Ribeiro MA (1973) The interaction of genotype with plant density and its implications in the assessment of material for breeding perennial ryegrass (Lolium perenne). In: Evaluation of Breeding Material in Herbage Crop. Rep EUCARPIA Fodder Crop Section Meeting, Dublin, Eire 1972, 7-31

Yonezawa K (1985) A definition of the optimal allocation of effort in conservation of plant genetic resources with application to sample size determination for field collection. Euphytica 34, 345-354 